\title{
Bacillus methylotrophicus sp. nov., a methanol- utilizing, plant-growth-promoting bacterium isolated from rice rhizosphere soil
}

\author{
Correspondence \\ Munusamy Madhaiyan \\ mmadhaiyan@hotmail.com
}

\author{
Munusamy Madhaiyan, ${ }^{1,2}$ Selvaraj Poonguzhali, ${ }^{1}$ Soon-Wo Kwon ${ }^{3}$ \\ and Tong-Min $\mathrm{Sa}^{1}$ \\ ${ }^{1}$ Department of Agricultural Chemistry, Chungbuk National University, Cheongju, \\ Chungbuk 361-763, Republic of Korea Singapore, Singapore 117604
${ }^{3}$ Korean Agricultural Culture Collection (KACC), Microbial Genetics Division, National Institute of Agricultural Biotechnology, RDA, Suwon 441-707, Republic of Korea \\ ${ }^{2}$ Biomaterials and Biocatalysts, Temasek Life Sciences Laboratory, The National University of
}

Methylotrophy has been recognized as a property of specialized bacteria that are capable of growth on C1compounds and members of numerous genera and species have been found to possess this ability (Whittenbury et al., 1970; Arfman et al., 1992; Kalyuzhnaya et al., 2006; Lidstrom, 2006). It has been found that the occurrence of methylotrophy in prokaryotes does not correlate with traditional bacterial classification (Brautaset et al., 2004), as facultative methylotrophy has been shown to be a property of diverse typically heterotrophic genera (Boden et al., 2008). One of the earliest methylotrophic organisms to be

Abbreviations: ACC, 1-aminocyclopropane-1-carboxylate deaminase; AMS, ammonium mineral salts; SEM, scanning electron microscope.

The GenBank/EMBL/DDBJ accession number for the 16S rRNA sequence of strain $\mathrm{CBMB}^{205^{\top}}$ is EU194897.

A photomicrograph of cells of strain $\mathrm{CBMB}^{205^{\top}}$ is available with the online version of this paper. isolated was the Gram-positive bacterium, 'Bacillus methylicus' (later renamed as 'Bacterium methylicum', but no longer available in culture). This aerobic, non-sporeforming, facultative methylotroph produced red pigment when grown on formate or methanol and also grew on formaldehyde (Loew, 1892; Migula, 1900; Bergey et al., 1939). Numerous specialized methylotrophs have since been described, including a great diversity of methanotrophs, some of which are obligate methane users, many that also use methanol and a few that are capable of growth on multicarbon compounds (Whittenbury et al., 1970; Dedysh et al., 2005). At the time of writing, the genus Bacillus, in the phylum Firmicutes, consisted of 225 species with validly published names (http://www.bacterio.cict.fr/ b/bacillus.html) with Bacillus subtilis as the type species (Cohn, 1872; Skerman et al., 1980). The genus includes the methanol-utilizing bacterium Bacillus methanolicus, which was isolated from soil samples (Arfman et al., 1992). 
Methylotrophic strains of the genus Bacillus display a strong resistance to high methanol concentrations and the molar growth yields on methanol at the optimum growth temperatures in methanol-limited chemostats are among the highest reported for any methylotrophic bacteria (Anthony, 1982; Dijkhuizen et al., 1988). Currently Gramnegative bacteria remain the best-studied plant-interacting microbes, but representatives of high and low G + C Grampositive bacteria also have excellent biocontrol, plant-growthpromoting and bioremediation activities. In addition, actinorhizal symbioses largely contribute to global biological nitrogen fixation and many Gram-positive bacteria promote other types of symbioses in tripartite interactions (Francis et al., 2010). In this paper, a novel species of the genus Bacillus was isolated from the rice rhizoplane and was found to have the ability to produce 1-aminocyclopropane-1-carboxylate deaminase (ACC deaminase).

Strain CBMB2 $205^{\mathrm{T}}$ was isolated from the rhizoplane of rice (Oryza sativa L. cv O-dae) from samples collected by the Chungbuk Provincial Agricultural Research and Extension Services (Cheongwon, Republic of Korea). The strain was isolated on selective ammonium mineral salts (AMS) medium (Whittenbury et al., 1970) supplemented with filter-sterilized cycloheximide $\left(10 \mu \mathrm{g} \mathrm{ml}^{-1}\right)$ and methanol $0.5 \%(\mathrm{v} / \mathrm{v})$ at $28{ }^{\circ} \mathrm{C}$ for 5 days. The cells were maintained on AMS medium with $0.5 \%(\mathrm{v} / \mathrm{v})$ methanol or on nutrient agar (NA, Difco) with $1 \%$ methanol (v/v). Morphological properties were studied according to general protocols (Gerhardt et al., 1994). The nutritional features were determined using Biolog GP2 microplates (Madhaiyan et al., 2007a; Poonguzhali et al., 2006) and carbon-source utilization tests (excluding Biolog) were performed using standard protocols (Green \& Bousfield, 1982). Gram staining was performed by using a Gram staining kit (Difco) and bacterial suspensions were examined by phasecontrast microscopy for cell morphology and motility. The $\mathrm{pH}$ range for growth was determined on R2A agar. The growth temperature range $\left(4,10,20,25,30,37,45^{\circ} \mathrm{C}\right)$ and $\mathrm{NaCl}$ tolerance $[0,1,2,3,4,5,10 \%(\mathrm{w} / \mathrm{v})]$ were tested on $\mathrm{R} 2 \mathrm{~A}$ medium. All tests were incubated at $28{ }^{\circ} \mathrm{C}$, unless otherwise indicated. Growth on nutrient agar, LuriaBertani (LB), R2A, trypticase soy agar (Difco), King's B medium (KB), 2\% MH (see DSMZ list of media 620, http://www.dsmz.de/microorganisms/media_list.php), and Colby and Zathman medium was also evaluated at $30{ }^{\circ} \mathrm{C}$. Catalase activity was determined by assessing bubble production in $3 \%(\mathrm{v} / \mathrm{v}) \mathrm{H}_{2} \mathrm{O}_{2}$ and oxidase activity was determined using $1 \%(\mathrm{w} / \mathrm{v})$ tetramethyl- $\rho$-phenylenediamine using Difco BBL catalase and oxidase reagent droppers according to the manufacturer's instructions (Difco). Tests for the hydrolysis of casein, glycerol tributyrate, gelatin, aesculin and pectin were performed and evaluated after 5 days (Atlas, 1993; Kouker \& Jaeger, 1987; Ten et al., 2004). Other physiological and biochemical characteristics were tested using the API ZYM, API 20NE and API 32GN galleries (bioMérieux) following the manufacturer's instructions. Preparation and examination of cells under a scanning electron microscope (SEM) was carried out according to Bozzola \& Russell (1998). Cells were visualized using a Hitachi S-2500C SEM with a GEMINI column equipped with a field-emission electron source. Cells of strain CBMB20 $5^{\mathrm{T}}$ were Gram-positive rods, aerobic, motile, endospore-forming, frequently branched and occurred singly or in pairs on solid AMS medium. Colonies were creamy white and convex with regular margins. Photomicrographs of cells of strain CBMB205 ${ }^{\mathrm{T}}$ grown on the solid surface of AMS medium supplemented with $0.5 \%$ methanol are shown in Supplementary Fig. S1 (available with IJSEM Online). The novel strain grew on methanol and on diethanolamine and showed weak growth on trimethylamine and formaldehyde when they were supplemented as a carbon source in AMS medium $(0.5 \%$ $\mathrm{v} / \mathrm{v}$ ). The results of nutrient utilization tests and the results from the API 20NE, API $32 \mathrm{GN}$ galleries for strain CBMB205 $5^{\mathrm{T}}$ are compared with those of closely related species of the genus Bacillus in Table 1.

The 16S rRNA gene was amplified by PCR from extracted DNA using the universal primers $27 \mathrm{~F}$ and 1492R (DeLong, 1992). The full gene sequence was determined by the fluorescent dye terminator method using the ABI Prism Big Dye Terminator Cycle Sequencing Ready Reaction kit (version 3.1). The products were run on a ABI3730XL capillary DNA sequencer (ABI Prism 310 Genetic Analyzer). Sequence comparisons with close relatives available from GenBank were performed using BLAST (http://www.ncbi. nlm.nih.gov.proxy.lib.siu.edu/blast/) to determine an approximate phylogenetic affiliation and sequences were aligned using CLUSTAL w (Thompson et al., 1994). Phylogenetic trees were constructed with the neighbour-joining (Saitou \& Nei, 1987) and maximum-parsimony (Fitch, 1971) methods, using the MEGA 4.1 program (Tamura et al., 2007) and bootstrap values based on 1000 replications (Felsenstein, 1985). The results revealed that strain $\mathrm{CBMB}^{205^{\mathrm{T}}}$ was phylogenetically affiliated to the genus Bacillus, forming a phyletic lineage within the genus with a bootstrap value of $37 \%$. Strain CBMB205 ${ }^{\mathrm{T}}$ was closely related to Bacillus vallismortis, Bacillus licheniformis, Bacillus subtilis, Bacillus mojavensis, Bacillus atrophaeus and Bacillus amyloliquefaciens showing pairwise sequence similarities ranging from 98.2 to $99.2 \%$ (Fig. 1).

Determination of ACC deaminase activity by plate and quantitative assays and tests for indole-3-acetic acid (IAA) production, sodium thiosulfate oxidation and siderophore production were carried out as described previously (Poonguzhali et al., 2006; Madhaiyan et al., 2006). A gnotobiotic growth pouch assay was performed to measure the degree of root elongation induced by ACC deaminase in tomato, canola and red pepper as these species are good representatives of ethylene sensitive plants (Glick et al., 1994; Li et al., 2000; Penrose \& Glick, 2003; Ghosh et al., 2003; Madhaiyan et al., 2006, 2007b). Strain CBMB205 ${ }^{\mathrm{T}}$ possessed ACC deaminase activity, showed siderophore production and sulfur oxidation activity when tested by plate assays and produced negligible amounts of IAA (data 
Table 1. Differential characteristics of strain $\mathrm{CBMB}^{205^{\top}}$ and some related species of the genus Bacillus

Strains: 1, CBMB205 ${ }^{\mathrm{T}}$; 2, B. amyloliquefaciens KACC $12067^{\mathrm{T}}$; 3, B. vallismortis NRRL B-14890 ${ }^{\mathrm{T}}$; 4, B. subtilis subsp. subtilis KACC $10854^{\mathrm{T}}$; 5 , B. subtilis subsp. spizizenii NRRL B-23049 ${ }^{\mathrm{T}}$; 6, B. atrophaeus NRRL NRS-213 ${ }^{\mathrm{T}}$; 7, B. mojavensis NRRL B-14698 ${ }^{\mathrm{T}}$; 8, B. licheniformis $\mathrm{KACC}^{10476^{\mathrm{T}}}$; 9 , B. methanolicus DSM $16454^{\mathrm{T}}$. All the isolates were positive for motility and catalase; negative for nitrate reduction to $\mathrm{N}_{2}$ and methylamine. In assimilation tests (API 20NE and API 32GN): all taxa were positive for aesculin hydrolysis, gelatin hydrolysis, D-glucose, D-mannose, D-mannitol, $\mathrm{N}$-acetylglucosamine, maltose, L-alanine, glycogen, L-proline and potassium gluconate. All taxa were negative for indole production, glucose fermentation, itaconic acid, suberic acid, sodium malonate, potassium 5-ketogluconate, 3-hydroxybenzoic acid, L-serine, L-fucose, capric acid, potassium 2-ketogluconate, 3-hydroxybutyric acid, 4-hydroxybenzoic acid and phenylacetic acid. +, Growth; -, no growth; w, weak growth. All data were obtained in this study.

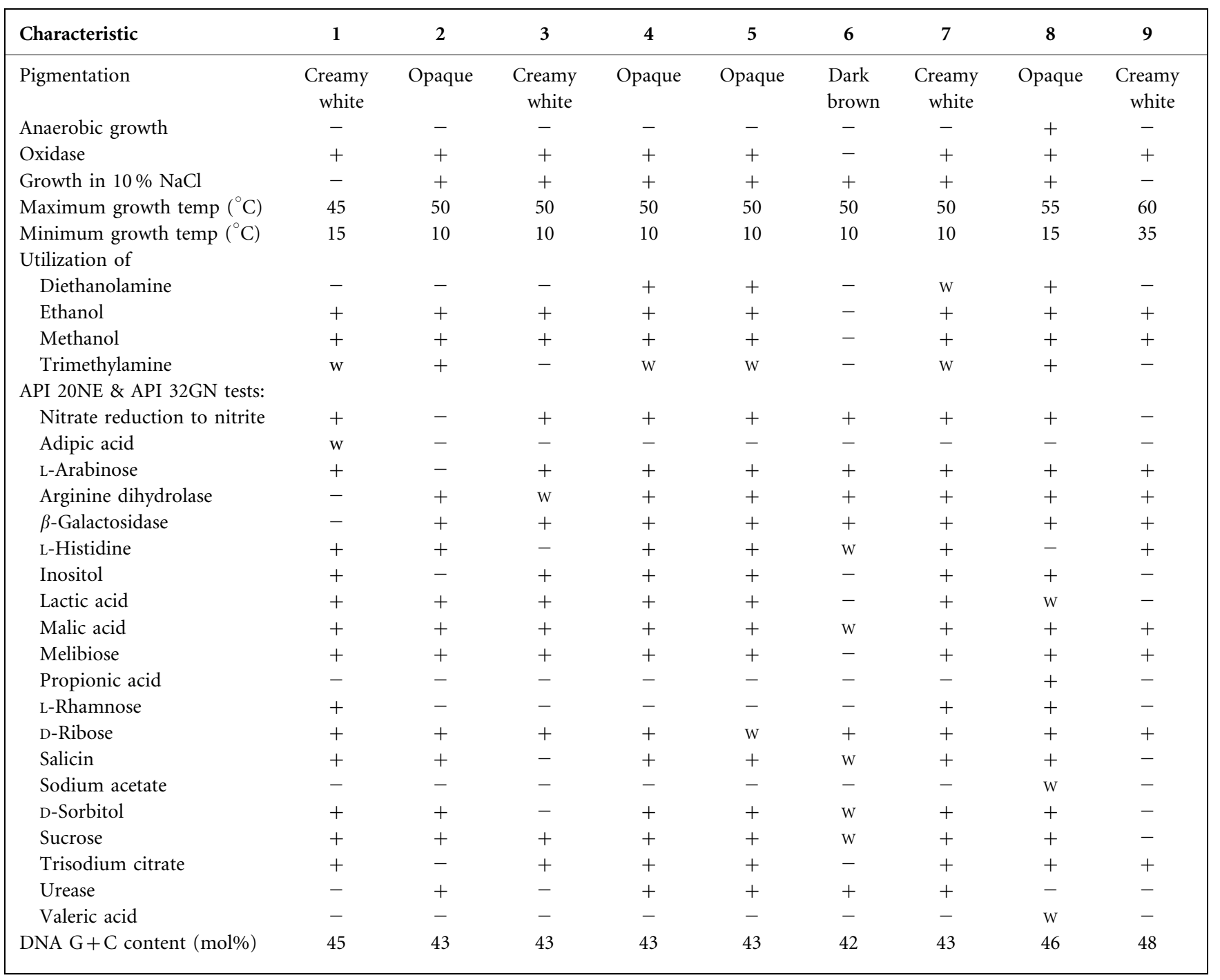

not shown). The ACC deaminase activity in cell-free extracts of strain $\mathrm{CBMB} 205^{\mathrm{T}}$ was $8.25 \mathrm{nmol} \alpha$-ketobutyrate per mg protein $h^{-1}$. The promotion of root elongation by strain $\mathrm{CBMB} 205^{\mathrm{T}}$ was checked with ethylene sensitive plants instead of with rice (the host crop), to verify the role of ACC deaminase in lowering the ethylene level. Inoculation of strain $\mathrm{CBMB} 205^{\mathrm{T}}$ increased the root lengths of tomato, red pepper and canola plants by $38.3,4.2$ and $22.4 \%$ over controls, respectively. Inoculation also increased the dry biomass of the plants (data not shown). The presence of the acdS gene (558 bp), encoding ACC deaminase, was confirmed in the novel strain by detection with PCR amplification using the non-degenerate primers F1936 and F1939 (Blaha et al., 2006). The presence of ACC deaminase in members of the genus Methylobacterium and various other bacterial genera has been reported previously (Madhaiyan et al., 2006, Penrose \& Glick, 2001; Belimov et al., 2001). The novel strain did not show acetylene reduction activity, which was performed in order to indicate the presence of the nitrogenase enzyme. However, the presence of the nifH gene in the novel strain was confirmed by PCR amplification carried out with specific 


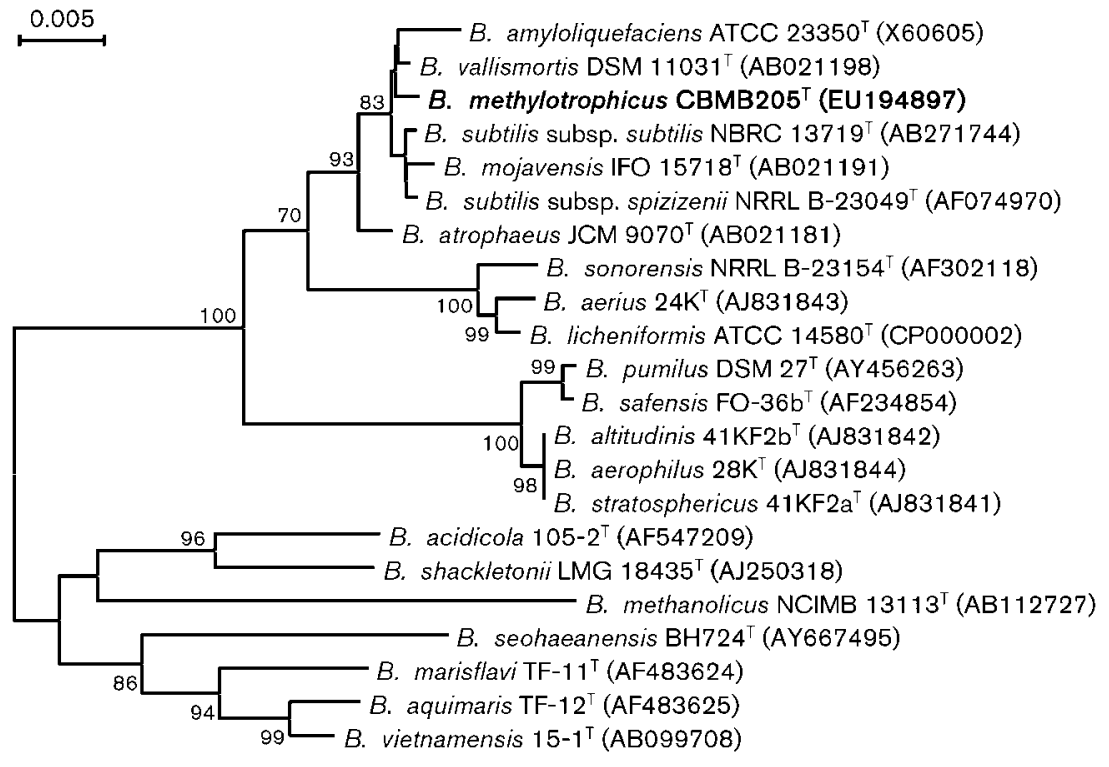

Fig. 1. Phylogenetic tree based on $16 \mathrm{~S}$ rRNA gene sequence comparisons showing the position of strain $\mathrm{CBMB}^{205^{\top}}$ and related species of the genus Bacillus. Numbers at nodes indicate percentages of occurrence in 1000 bootstrapped trees; bootstrap values $<70 \%$ are not shown. Bar, $0.005 \%$ substitutions per site. primers (Ueda et al., 1995) 19F (5'-GCIWTYTAYGGIAARGGIGG-3') and 407R (5'-AAICCRCCRCAIACIACRTC-3').

For the analysis of cellular fatty acids, the novel strain was cultured in trypticase soy agar at $28{ }^{\circ} \mathrm{C}$ for $48 \mathrm{~h}$. The fatty acids were extracted, derivatized to methyl esters and analysed by GC (6890; Hewlett Packard) using the Microbial Identification System (MIDI; Microbial ID) software package, according to standard protocols (Sasser, 1990). Polar lipids and menaquinones were extracted and analysed according to Minnikin et al. (1984) and Kroppenstedt (1982). Preparation of cell walls from strain CBMB205 ${ }^{\mathrm{T}}$ and the analysis of peptidoglycan were carried out using methods described by Schleifer

Table 2. Cellular fatty acid contents of strain $\mathrm{CBMB}^{205^{\top}}$ and type strains of related Bacillus species

Strains: 1, CBMB205 ${ }^{\mathrm{T}}$; 2, B. amyloliquefaciens KACC $12067^{\mathrm{T}}$; 3, B. vallismortis NRRL B-14890 ${ }^{\mathrm{T}} ; 4, B$. subtilis subsp. subtilis $\mathrm{KACC}$ $10854^{\mathrm{T}}$; 5, B. subtilis subsp. spizizenii NRRL B-23049 ${ }^{\mathrm{T}} ; 6, \quad$ B. atrophaeus NRRL NRS-213 ${ }^{\mathrm{T}} ; 7$, B. mojavensis NRRL B-14698 ${ }^{\mathrm{T}} ; 8$, B. licheniformis KACC $10476^{\mathrm{T}}$; 9, B. methanolicus DSM $16454^{\mathrm{T}}$. Values are percentages of total fatty acids. Fatty acids representing $<0.1 \%$ in all strains were omitted. All data were obtained in this study.

\begin{tabular}{|c|c|c|c|c|c|c|c|c|c|}
\hline Fatty acid & 1 & 2 & 3 & 4 & 5 & 6 & 7 & 8 & 9 \\
\hline $\mathrm{C}_{14: 0}$ iso & - & 2.9 & 1.2 & 1.3 & 1.5 & 1.9 & 1.1 & 1.1 & 0.9 \\
\hline $\mathrm{C}_{15: 0}$ iso & 20.8 & 21.5 & 17.5 & 28.6 & 29.2 & 14.5 & 25.2 & 33.6 & 27.5 \\
\hline $\mathrm{C}_{15: 0}$ anteiso & 52.7 & 44.2 & 49.5 & 44.2 & 42.5 & 50.2 & 46.5 & 43.6 & 32.5 \\
\hline $\mathrm{C}_{16: 0}$ & - & 8.5 & 5.6 & 4.5 & 4.4 & 5.2 & 5.5 & 4.6 & 5.7 \\
\hline $\mathrm{C}_{16: 0}$ iso & 13.9 & - & - & 2.2 & 2.1 & - & - & - & 11.2 \\
\hline $\mathrm{C}_{17: 0}$ iso & - & 9.7 & 8.6 & 8.9 & 8.5 & 9.5 & 9.1 & 6.5 & 6.1 \\
\hline $\mathrm{C}_{17: 0}$ anteiso & 12.6 & 12.5 & 17.5 & 9.6 & 11.2 & 17.9 & 11.5 & 10.5 & 15.8 \\
\hline
\end{tabular}

(1985), with the modification that TLC was performed on cellulose sheets rather than by paper chromatography. The fatty acid profile of the strain CBMB205 ${ }^{\mathrm{T}}$ consisted mainly of $\mathrm{C}_{15: 0}$ anteiso, $\mathrm{C}_{15: 0}$ iso, $\mathrm{C}_{16: 0}$ iso and $\mathrm{C}_{17: 0}$ anteiso (summarized in Table 2).

DNA-DNA hybridization experiments were performed to determine the relatedness of strain $\mathrm{CBMB} 205^{\mathrm{T}}$ to its closest relatives. The filter hybridization method was used (Seldin \& Dubnau, 1985). The hybridization temperature was $65{ }^{\circ} \mathrm{C}$ and DNA-DNA relatedness was quantified by using a densitometer (Bio-Rad Laboratories). Probe labelling was conducted by using the non-radioactive DIG-High prime system (Roche Diagnostics $\mathrm{GmbH}$ ) and hybridized DNA was visualized using the DIG Luminescent Detection kit according to the manufacturer's instructions (Roche Diagnostics $\mathrm{GmbH}$ ). The $\mathrm{G}+\mathrm{C}$ content of the genomic DNA of the novel strain was determined by HPLC analysis using a reverse-phase column (Supelcosil LC-18 S, Supelco) of individual nucleosides as previously described (Mesbah et al., 1989). Strain CBMB205 ${ }^{\mathrm{T}}$ showed a low level of DNA-DNA relatedness that ranged from 19.0 to $6.0 \%$ with its closest relatives B. amyloliquefaciens $(36.0 \%), B$. vallismortis $(32 \%), B$. subtilis subsp. subtilis $(31 \%)$, B. subtilis subsp. spizizenii (30\%), B. atrophaeus (28\%), B. licheniformis $(25 \%)$ and B. mojavensis (19\%). These results indicated that strain $\mathrm{CBMB} 205^{\mathrm{T}}$ did not belong to the above species if the recommended threshold value of $70 \%$ DNA-DNA similarity for the delineation of species is considered (Wayne et al., 1987). The DNA G + C content of strain CBMB205 ${ }^{\mathrm{T}}$ was $45.0 \mathrm{~mol} \%$, which fell within the range previously described for the genus Bacillus.

The 16S rRNA gene sequence similarity data, DNA-DNA hybridization values and other phenotypic characteristics allowed strain $\mathrm{CBMB} 205^{\mathrm{T}}$ to be recognized as separate from other members of the genus Bacillus. On the basis of these results, strain $\mathrm{CBMB} 205^{\mathrm{T}}$ is considered to represent a 
novel species of the genus Bacillus, for which the name Bacillus methylotrophicus sp. nov. is proposed.

\section{Description of Bacillus methylotrophicus sp. nov.}

Bacillus methylotrophicus [me.thy.lo.tro.phi.cus. N.L. suff. methylo pertaining to the methyl radical; N.L. adj. trophicus (from Gr. adj. trophikos) nursing, tending or feeding; N.L. masc. adj. methylotrophicus feeding on methyl radical, methyl radical-consuming].

Gram-positive, endospore-forming, strictly aerobic, motile rods $(0.63-0.64 \times 1.8-2.7 \mu \mathrm{m})$ occurring singly or in pairs. Colonies are creamy white, convex, translucent with regular edges, slow-growing and $0.2-0.8 \mathrm{~mm}$ in diameter after $96 \mathrm{~h}$ at $28{ }^{\circ} \mathrm{C}$ on AMS. Grows on NA, LB, R2A, TSA, $\mathrm{KB}, 2 \% \mathrm{MH}$ and Colby and Zathman medium. Does not grow in the presence of $>4.0 \%(\mathrm{w} / \mathrm{v}) \mathrm{NaCl}$. Growth occurs at $20-45{ }^{\circ} \mathrm{C}$ (optimal temperature $28{ }^{\circ} \mathrm{C}$ ) and at $\mathrm{pH} 2.0$ 10.0 (optimal pH 7.0). Catalase, oxidase, pectinase and protease activities are positive. Cellulase, arginine dihydrolase, urease and $\beta$-galactosidase activities are absent. Nitrate reduction and hydrolysis of gelatin, glycerol tributyrate and aesculin are positive. Tests for glucose fermentation and indole production are negative. Methanol, trimethylamine and ethanol are utilized as sole carbon sources. Ammonium sulfate, potassium nitrate, sodium nitrate, ammonium chloride, L-alanine, L-glutamine, Ltryptophan, glycine, trimethylamine, 1-aminocyclopropane-1-carboxylate, potassium cyanate and potassium thiocyanate are utilized as sole nitrogen sources, but urea, methylamine, L-glutamate, diphenylamine and L-aspartic acid are not utilized as nitrogen sources. None of the compounds in Biolog tests are utilized as sole carbon and energy sources. The following carbon and nitrogen sources are assimilated in the API 20NE test: D-glucose, Larabinose, D-mannose, D-mannitol, $\mathrm{N}$-acetylglucosamine, maltose, potassium gluconate, adipic acid, malic acid and trisodium citrate. Negative for capric acid and phenylacetic acid. The following carbon sources are assimilated in the API 32GN test: $N$-acetylglucosamine, D-ribose, inositol, sucrose, maltose, lactic acid, L-alanine, glycogen, D-mannitol, D-glucose, salicin, melibiose, L-rhamnose, D-sorbitol, L-arabinose, trisodium citrate, L-histidine and L-proline. Negative for itaconic acid, suberic acid, sodium malonate, sodium acetate, potassium 5-ketogluconate, 3-hydroxybenzoic acid, L-serine, L-fucose, propionic acid, capric acid, valeric acid, potassium 2-ketogluconate, 3-hydroxybutyric acid and 4-hydroxybenzoic acid. In API ZYM assays, alkaline phosphatase, esterase (C4), esterase lipase (C8), naphthol-AS-BI-phosphohydrolase and $\alpha$-glucosidase are present, but lipase (C14), leucine arylamidase, trypsin, acid phosphatase, valine arylamidase, cystine arylamidase, $\alpha$-chymotrypsin, $\alpha$-galactosidase, $\beta$-galactosidase, $\beta$-glucuronidase, $\beta$-glucosidase, $N$-acetyl $-\beta$-glucosaminidase, $\alpha$-mannosidase and $\alpha$-fucosidase are absent. The cell wall contains meso-diaminopimelic acid as the diagnostic diamino acid. Predominant polar lipids are diphosphatidylglycerol, phosphatidylglycerol, a minor amount of phosphatidylcholine and two unknown phospholipids. The major respiratory quinone is MK-7. Major cellular fatty acids are $\mathrm{C}_{15: 0}$ anteiso, $\mathrm{C}_{15: 0}$ iso, $\mathrm{C}_{16: 0}$ iso and $\mathrm{C}_{17: 0}$ anteiso.

The type strain, $\mathrm{CBMB}_{20} 5^{\mathrm{T}}\left(=\mathrm{KACC} 13105^{\mathrm{T}}=\mathrm{NCCB}\right.$ 100236), was isolated from the rhizoplane of rice (Oryza sativa $\mathrm{L}$. cv O-dae). The sample was collected at reproductive stage (R9) and was obtained from the Chungbuk Provincial Agricultural Research and Extension Services, Cheongwon ( $\left.36^{\circ} 58^{\prime} 0^{\prime \prime} \mathrm{N}, 127^{\circ} 57^{\prime} 0^{\prime \prime} \mathrm{E}\right)$, Chungbuk, Republic of Korea. The DNA G + C content of the type strain is $45.0 \mathrm{~mol} \%$.

\section{Acknowledgements}

M.M. is indebted to the BrainKorea21, Republic of Korea, for a position as an invited scientist. The author also acknowledges support from the Rural Development Administration, Republic of Korea.

\section{References}

Anthony, C. (1982). The Biochemistry of Methylotrophs. London: Academic Press.

Arfman, N., Dijkhuizen, L., Kirchhof, G., Ludwig, W., Schleifer, K.-H., Bulygina, E. S., Chumakov, K. M., Govorukhina, N. I., Trotsenko, Y. A. \& other authors (1992). Bacillus methanolicus sp. nov., a new species of thermotolerant, methanol utilizing, endospore-forming bacteria. Int J Syst Bacteriol 42, 439-445.

Atlas, R. M. (1993). Handbook of Microbiological Media. Edited by L. C. Parks. Boca Raton, FL: CRC Press.

Belimov, A. A., Safronova, V. I., Sergeyeva, T. A., Egorova, T. N., Matveyeva, V. A., Tsyganov, V. E., Borisov, A. Y., Tikhonovich, I. A., Kluge, C. \& other authors (2001). Characterization of plant growth promoting rhizobacteria isolated from polluted soils and containing 1-aminocyclopropane-1-carboxylate deaminase. Can J Microbiol 47, 642-652.

Bergey, D. H., Breed, R. S., Murray, E. G. D. \& Hitchens, A. P. (1939). Bacterium methylicum (Loew) Migula. (Bacillus methylicus Loew). In Bergey's Manual of Determinative Bacteriology, 5th edn, p. 597. Edited by D. H. Bergey, R. S. Breed, E. G. D. Murray \& A. P. Hitchens. London, UK: Baillière, Tindall \& Cox.

Blaha, D., Prigent-Combaret, C., Sajjad Mirza, M. \& Moënne-Loccoz, Y. (2006). Phylogeny of the 1-aminocyclopropane-1-carboxylic acid deaminase-encoding gene acdS in phytobeneficial and pathogenic Proteobacteria and relation with strain biogeography. FEMS Microbiol Ecol 56, 455-470.

Boden, R., Thomas, E., Savani, P., Kelly, D. P. \& Wood, A. P. (2008). Novel methylotrophic bacteria isolated from the River Thames (London, UK). Environ Microbiol 10, 3225-3236.

Bozzola, J. J. \& Russell, L. D. (1998). Electron Microscopy, 2nd edn. Sudbury, MS: Jones \& Bartlett.

Brautaset, T., Jakobsen, O. M., Flickinger, M. C., Valla, S. \& Ellingsen, T. E. (2004). Plasmid-dependent methylotrophy in thermotolerant Bacillus methanolicus. J Bacteriol 186, 1229-1238.

Cohn, F. (1872). Untersuchungen über Bakterien. Beitr Biol Pflanz 1, 127-224 (in German).

Dedysh, S. N., Knief, C. \& Dunfield, P. F. (2005). Methylocella species are facultatively methanotrophic. J Bacteriol 187, 4665-4670.

DeLong, E. F. (1992). Archaea in coastal marine environments. Proc Natl Acad Sci U S A 89, 5685-5689. 
Dijkhuizen, L., Arfmann, N., Attwood, M. M., Brooke, A. G., Harder, W. \& Watling, E. M. (1988). Isolation and initial characterization of thermotolerant methylotrophic Bacillus strains. FEMS Microbiol Lett 52, 209-214.

Felsenstein, J. (1985). Confidence limits on phylogenies: an approach using the bootstrap. Evolution 39, 783-791.

Fitch, W. M. (1971). Toward defining the course of evolution: minimum change for a specific tree topology. Syst Zool 20, 406-416.

Francis, I., Holsters, M. \& Vereecke, D. (2010). The Gram-positive side of plant-microbe interactions. Environ Microbiol 12, 1-12.

Gerhardt, P. R., Murray, R. G. E., Wood, W. A. \& Krieg, N. R. (editors) (1994). Methods for General and Molecular Bacteriology. Washington, DC: American Society for Microbiology.

Ghosh, S., Penterman, J. N., Little, R. D., Chavez, R. \& Glick, B. R. (2003). Three newly isolated plant growth-promoting bacilli facilitate the seedling growth of canola, Brassica campestris. Plant Physiol Biochem 41, 277-281.

Glick, B. R., Jacobson, C. B., Schwarze, M. M. K. \& Pasternak, J. J. (1994). 1-Aminocyclopropane-1-carboxylic acid deaminase mutants of the plant growth promoting rhizobacterium Pseudomonas putida GR12-2 do not stimulate root elongation. Can J Microbiol 40, 911915.

Green, P. N. \& Bousfield, I. J. (1982). A taxonomic study of some Gram-negative facultatively methylotrophic bacteria. J Gen Microbiol 128, 623-638.

Kalyuzhnaya, M. G., De Marco, P., Bowerman, S., Pacheco, C. C., Lara, J. C., Lidstrom, M. E. \& Chistoserdova, L. (2006). Methyloversatilis universalis gen. nov., sp. nov., a novel taxon within the Betaproteobacteria represented by three methylotrophic isolates. Int J Syst Evol Microbiol 56, 2517-2522.

Kouker, G. \& Jaeger, K.-E. (1987). Specific and sensitive plate assay for bacterial lipase. Appl Environ Microbiol 53, 211-213.

Kroppenstedt, R. M. (1982). Separation of bacterial menaquinones by HPLC using reverse phase (RP18) and a silver loaded ion exchanger as stationary phases. J Liq Chromatogr 5, 2359-2367.

Li, J., Ovakim, D. H., Charles, T. C. \& Glick, B. R. (2000). An ACC deaminase minus mutant of Enterobacter cloacae UW4 no longer promotes root elongation. Curr Microbiol 41, 101-105.

Lidstrom, M. E. (2006). Aerobic methylotrophic prokaryotes. In The Prokaryotes, vol. 2, pp. 618-634. Edited by M. Dworkin, S. Falkow, E. Rosenberg, K.-H. Schleifer \& E. Stackebrandt. NY, USA: SpringerVerlag.

Loew, O. (1892). Ueber einen Bacillus, welcher Ameisensäure und Formaldehyd assimilieren kann. Centralbl Bakteriol 12, 462-465 (in German).

Madhaiyan, M., Poonguzhali, S., Ryu, J.-H. \& Sa, T.-M. (2006). Regulation of ethylene levels in canola (Brassica campestris) by 1aminocyclopropane-1-carboxylate deaminase-containing Methylobacterium fujisawaense. Planta 224, 268-278.

Madhaiyan, M., Kim, B.-Y., Poonguzhali, S., Kwon, S.-W., Song, M.-H., Ryu, J.-H., Go, S.-J., Koo, B.-S. \& Sa, T.-M. (2007a). Methylobacterium oryzae sp. nov., an aerobic, pink-pigmented, facultatively methylotrophic, 1-aminocyclopropane-1-carboxylate deaminase-producing bacterium isolated from rice. Int J Syst Evol Microbiol 57, 326-331.

Madhaiyan, M., Poonguzhali, S. \& Sa, T.-M. (2007b). Characterization of 1-aminocyclopropane-1-carboxylate (ACC) deaminase containing Methylobacterium spp. and interactions with auxins and ACC regulation of ethylene in canola. Planta 226, 867876.
Mesbah, M., Premachandran, U. \& Whitman, W. B. (1989). Precise measurement of the $\mathrm{G}+\mathrm{C}$ content of deoxyribonucleic acid by highperformance liquid chromatography. Int J Syst Bacteriol 39, 159-167.

Migula, W. (1900). Bacterium methylicum (Loew) Migula. In System der Bakterien. Handbuch der Morphologie, Entwicklungsgeschichte und Systematik der Bakterien, vol. 2, pp. 447-448. Jena: Verlag von Gustav Fischer.

Minnikin, D. E., O'Donnell, A. G., Goodfellow, M., Alderson, G., Athalye, M., Schaal, A. \& Parlett, J. H. (1984). An integrated procedure for the extraction of bacterial isoprenoid quinones and polar lipids. J Microbiol Methods 2, 233-241.

Penrose, D. M. \& Glick, B. R. (2001). Levels of ACC and related compounds in exudate and extracts of canola seeds treated with ACC deaminase containing plant growth-promoting bacteria. Can $J$ Microbiol 47, 368-372.

Penrose, D. M. \& Glick, B. R. (2003). Methods for isolating and characterizing ACC deaminase-containing plant growth-promoting rhizobacteria. Physiol Plant 118, 10-15.

Poonguzhali, S., Madhaiyan, M. \& Sa, T. M. (2006). Cultivationdependent characterization of rhizobacterial communities from field grown Chinese cabbage Brassica campestris ssp pekinensis and screening of traits for potential plant growth promotion. Plant Soil 286, 167-180.

Saitou, N. \& Nei, M. (1987). The neighbor-joining method: a new method for reconstructing phylogenetic trees. Mol Biol Evol 4, 406425.

Sasser, M. (1990). Identification of bacteria through fatty acid analysis. In Methods in Phytobacteriology, pp. 199-204. Edited by S. Klement, K. Rudolf \& D. Sands. Budapest: Akademiai Kiado.

Schleifer, K. H. (1985). Analysis of the chemical composition and primary structure of murein. Methods Microbiol 18, 123-156.

Seldin, L. \& Dubnau, D. (1985). Deoxyribonucleic acid homology among Bacillus polymyxa, Bacillus macerans, Bacillus azotofixans, and other nitrogen-fixing Bacillus strains. Int J Syst Bacteriol 35, 151-154.

Skerman, V. B. D., McGowan, V. \& Sneath, P. H. A. (editors) (1980). Approved lists of bacterial names. Int J Syst Bacteriol 30, 225-420.

Tamura, K., Dudley, J., Nei, M. \& Kumar, S. (2007). MEGA4: molecular evolutionary genetics analysis (MEGA) software version 4.0. Mol Biol Evol 24, 1596-1599.

Ten, L. N., Im, W.-T., Kim, M.-K., Kang, M.-S. \& Lee, S.-T. (2004). Development of a plate technique for screening of polysaccharide degrading microorganisms by using a mixture of insoluble chromogenic substrates. J Microbiol Methods 56, 375-382.

Thompson, J. D., Higgins, D. G. \& Gibson, T. J. (1994). CLUSTAL w: improving the sensitivity of progressive multiple sequence alignment through sequence weighting, position-specific gap penalties and weight matrix choice. Nucleic Acids Res 22, 4673-4680.

Ueda, T., Suga, Y., Yahiro, N. \& Matsuguchi, T. (1995). Remarkable $\mathrm{N}_{2}$-fixing bacterial diversity detected in rice roots by molecular evolutionary analysis of nifH gene sequences. J Bacteriol 177, 14141417.

Wayne, L. G., Brenner, D. J., Colwell, R. R., Grimont, P. A. D., Kandler, O., Krichevsky, M. I., Moore, L. H., Moore, W. E. C., Murray, R. G. E. \& other authors (1987). International Committee on Systematic Bacteriology. Report of the ad hoc committee on reconciliation of approaches to bacterial systematics. Int J Syst Bacteriol 37, 463-464.

Whittenbury, R., Davies, S. L. \& Wilkinson, J. F. (1970). Enrichment, isolation and some properties of methane-utilizing bacteria. J Gen Microbiol 61, 205-218. 